\title{
The penetration of foreings in the terminology of some vital areas in Albania and Kosovo
}

\author{
MA. sc. Shpresa Dorda \\ Specialists of Curricula into Educational \\ Regional Directory of Tirana (Ph.D. Candidate) \\ shpresa.dorda@yahoo.com
}

\begin{abstract}
Dr. sc. Sindorela DOLI - KRYEZIU
Lecturer at the University of Gjakova,

Prizren and Pristina

sindidol@yahoo.com
\end{abstract}

MA. Sc. Gentian Muhaxhiri

Lecturer at the University of Gjakova

(Ph.D. Candidate)

gentianamuhaxhiri@hotmail.com

\section{Abstract}

\begin{abstract}
Albanian language in its current shape is conditioned by historical factors, social, economic, political, and by internal factors of its development. An important direction of development of language is dealing with borrowings, once they benefited from this mutual enrichment between languages in contact, the times words are superimposed where the consequences are evident in the course of development of the host language. Even the Albanian language has a similar approach as both in Albania and Kosovo. Her relationship with neighboring languages, and not only with them, have made her face be the result and reflection of this phenomenon. The trend/tendence of recent years of Albanian people using foreign words as a result of political and social factors we have observed in Albania and Kosovo. Languages of which we have received most borrowings word are mainly from two countries English, Italian and less from French.Foreign words penetrated many vital aspects of the Albanians people life and in two countries. Given the fact of the establishment of linguistic culture, social, historical, we become aware that the development of technology, many expressions and borrowings have entered our daily lexicon , because, at the moment we have not made any our discovery and we don't have any real name to put to these objects. Even in various fields of science and technology are added borrowings, where the object or phenomenon introduced, along with the name of the language of the country that invented or issue.To further we have selected some areas terminology, such as administrative and legal terminology, language terminology, culinary, sports, information and technology. Examples of borrowings that we received from each area have given the sentence to get a context where there are used, except linguistic terminology for which we did not see it reasonable to give examples in sentences, since the paper work is in this area and only the term is sufficient.
\end{abstract}

Keywords: penetration, foreings, terminology, Albania, Kosovo

\section{Administrative - legal terminology}

The material of collecting foreign words, belonging to administrative, legal terminology is made of the Criminal Code (Kodi Penal) - The updated with judicial practice (I perditesuar me praktike gjuhesore), Tirana 2009, Civil Code (Kodi Civil), Tirana 2010, The Code of Administrative Procedure (Kodi i procedures administrative), Tirana 2009, The Code of Civil Procedure, Tirana 2007 , The Code of Criminal Procedure (Kodi i procedures penale), Family Code (Kodi i familjes) and legislation on adoption .

Below we have given foreign words into the sentence, so we can take the meaning which they broadcast.

Examples: 
- International agreements ratified by the Albanian state (Marrëveshje ndërkombëtare të ratifikuar nga shteti shqiptar).

- When the offense committed under the effect of narcotics (Kur vepra penale kryhet nën efektin e narkotikëve).

- The prosecutor asks the court to replace them with another sanction (Prokurori i kërkon gjykatës zëvendësimin e tyre me një sanksion tjetër).

- $\quad$ Obstructing or concealment of correspondence (Pengimi ose fshehja e correspondences)

- Consists in creating unfair privileges (Konsiston në krijimin e privilegjeve të padrejta).

- To create unfair privileges to third parties ( Për të krijuar dhe privilegje të padrejta për të tretët).

- When these claims related to the start pretedence (Kur këto të fundit kanë lidhje me pretendimet e fillimit).

- Can extend the deadline decision which is not preclusive (Mund të zgjasë me vendim afatin që nuk është prekluziv).

- Without court permission and without being evident in the file (Pa lejen e gjykatës dhe pa qenë të evidentuara në dosje).

- Without disclosing the person who is credited false (Pa treguar personin të cilit i atribuohet falsiteti).

- The chairman of the appellate court determines reporter of the case and the day of judgment (Kryetari i gjykatës së apelit cakton relatorin e çështjes dhe ditën e gjykimit).

- When the chairman consist on that it is not competent to put in execution request (Kur përmbaruesi gjyqësor konstaton se nuk është kompetent për të vënë në ekzekutim kërkesën).

- The buyer called the bidder that has offered the highest price (Blerësi quhet ofertuesi që ka dhënë çmimin më të lartë).

- Because of preference by other tasks, the execution order is returned to the creditor (Për shkak preference nga detyrime të tjera, urdhri i ekzekutimit i kthehet kreditorit).

- They have a right to be compensated for losses based on legal provisions (Kanë të drejtë të kompensohen për humbjet eventuale në bazë të dispozitave ligjore).

- It should respect the principle of proportionality (Duhet të respektojë parimin e proporcionalitetit).

- The purpose of asking to be realized with less repressive measures without compromising their effectiveness (Qëllimi i kërkuar të realizohet me masa sa më pak represive, pa kompromentuar efektivitetin e tyre).

- Put the destination of property that remains after its dissolution (Vendos për destinimin e pasurisë që mbetet pas shpërndarjes së saj).

- The day when awarding appropriate by the court or arbitration who was born lawsuit regression (Dita kur është dhënë vendimi i gjykatës ose arbitrazhi përkatës nga i cili ka lindur padia e regresit).

- Prediction of discontinued against one solidary debtors (Parashikimi i ndërprerë kundër njërit prej debitorëve solidarë).

- When a right may be exercised within a preclusive (Kur një e drejtë mund të ushtrohet brenda një afati prekluziv).

- Ownership of abandoned movable thing and equipment (Pronësia mbi sendet e luajtshme të abandonuara).

- Specify that in proportion to the benefits derived from it to build and maintain other means (Detyrohet që në proporcion me përfitimin që nxirret prej tij të ndërtoj edhe mirëmbajë mjetete tjera).

- The things can't be below average quality (Sendi nuk mund të jetë nën kualitetin mesatar).

- Conversion should be made at the official rate (Konvertimi duhet të bëhet me kursin zyrtar).

- In addition to sue possessory can exercise the claim of the recovery (Përveç padisë posedimore mund të ushtrojë edhe padinë e rivendikimit). 
- The warranty ineligible for evinksion if not proves that there is sufficient reason to stop taking the thing ( $E$ humb të drejtën e garancisë për evinksion në qoftë së nuk provon se nuk ekziston arsye e mjaftueshme për të penguar marrjen e sendit).

- The use of the property to another destination (Të përdorë sendin në një destinacion tjetër).

- Respect and mutual understanding, as the basis of unity in the family (Respekti dhe mirëkuptimi reciprok, si baza e unitetit në familje).

- There are entitled to regress to the other spouse for the obligation to repay on his behalf.( Ka të drejtën e regresit ndaj bashkëshortit tjetër për pjesën e detyrimit të shlyer për llogari të tij).

- In the absence of proof to the contrary is presumed that makes movable property participate in community (Në mungesë të provave të kundërta prezumohet se pasuria e luajtshme bën pjesë në bashkësi).

- Every clause of the contract is void if compels them (Çdo klauzolë e kontratës është e pavlefshme nëse detyron bashkëshorti).

- Being_related to the abusive exercise of parental responsibility (Janë të lidhura me ushtrimin abuziv të përgjegjësisë prindërore).

- Confirmation that the child was not able to adopted (Konfirmimin se i mituri nuk ka patur mundësi të birësohet)

- Adoption is irrevocable (Birësimi është i parevokueshëm).

- $\quad$ Public and legacies donations (Trashëgimitë dhe donacionet publike).

- Specify to protect the confidentiality and reliability (Detyrohet të ruajnë konfidencialitetin dhe besueshmërinë).

- They expressed or evidenced it in writing (Kanë shprehur ose evidentuar atë me shkrim).

- The interests of children are a primary consideration (Interesat e fëmijëve janë të një rëndësie prioritare).

- Information about the background (Informacion në lidhje me bekgraundin).

- No security, obligation or deposit can't ask for costs of guarantees payment (Asnjë siguracion, obligacion apo depozitë nuk mund të kërkojë garanci pagese kostosh).

- Children victim of potential trafficking (Fëmijë viktimë potenciale e trafikimit).

- Provision that prescribing the confiscation of all objects (Dispozita që paracaktojnë konfiskimin e të gjitha objekteve).

- Developing standards for fair and efficient collection of information (Hartimin e standardeve për mbledhjen e rregullt dhe eficente të informacionit).

- The existence of a fact can not be inferred from the indications except when these are important (Ekzistenca e një fakti nuk mund të nxirret nga indicjet përveçse kur këto janë të rëndësishme).

- During the interview the witness makes contradictory statements (Gjatë pyetjes dëshmitari bën thënie kontradiktore).

- Infiltration deadline may be extended by prosecutor (Afati i infiltrimit mund të zgjatet nga prokurori).

- Defenders of who have assisted in making their choise (Mbrojtësit e të cilëve kanë asistuar në marrjen e tyre).

- The witness may make inquiries into distance (Dëshmitari mund t'i bëjë pyetjet në distance).

The convict shall be subject persecutory or discriminatory acts (I dënuari do t'u nënshtrohet akteve presekutuese ose diskriminuese)

\section{Linguistic terminology}

We get linguistic terms from the "Glossary terms of linguistics"( Fjalor me terma gjuhesor), Tirana 2011, from the authors Giovanni Belluscio and Shezai Rokaj. Since the Albanian language has a dictionary like this we decided to take some terms to be presented as examples of terms in this field. 
Egxamples:

- adverbalizim - ndajfoljezim ( a d v e r b i a l)

- afiks - ndajshtesë (affix)

- aglutinim - përngjitje (agglutination)

- aklimatizim - përshtatje (n a turalization)

- $\quad$ akordim - bashkëpërshtatje (accordance)

- $\quad$ areal - hapësirë ( a r e a)

- $\quad$ infiks - brendashtesë ( i nfix)

- $\quad$ inkorporim - brendatrupësim (incorporation)

- eufoni - bukurtingëllim ( euphony)

- $\quad$ kakofoni - keqtingëllim (cacophony)

- $\quad k o l o f o n i-s h e ̈ n i m ~ i ~ b o t u e s i t(c o l o p h o n y)$

- cross-over - kapërcim i kryqëzuar (cross-over)

- deiks - tregor (index)

- deverbativ - prejfoljor (deverbation)

- diminutiv-zvogëlues (diminutive)

- $\quad$ ekuativ - shkallë krahasore e barazisë (equality)

- gradual - shkallëzuar (gradual)

- gutural - grykor (guttural)

- gjeneroj - prodhoj, (generate)

- $\quad$ iterative - përsëritës (iterative)

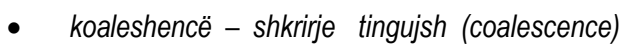

- konversion - shndërrim (convertion)

- kakuminal - kulmor (culmination)

- $\quad$ antencendent - paraprirës (preceding)

- kontrastiv - përqasës ( $c$ o $n t r$ a $s t i v$ e )

- $\quad$ ridondancë - fjalëtepri (wordiness)

- $\quad$ singularizuar - njëjësuar (singularized)

- translacion - zhvendosje ${ }^{1}$ (translation)

\section{Culinary terminology}

As source material for the collection of material culinary we have got two books, "The art of patisserie"( Arti i psticerise) Kosta Koci, Tirana 2005, and "The art of cooking" ( Arti i gatimit) Vangjel Kullaj, Mico Garuli, Tirana 1998, as well as programs on the basis of which are delicious cookies.

Egxamples:

\footnotetext{
1 Giovanni Belluscio, Shezai Rrokaj, Fjalor me terma të gjuhësisë, Tiranë 2011
} 
- Butter, softened by heat in the banjo - mari (Gjalpi zbutet duke u ngrohur në banjo - mari).

- There are many methods for the conservation of meat (.Për konservimin e mishit ka shumë metoda).

- $\quad$... the extractive that melt during cooking ... (..ekstraktive që shkrihen gjatë zierjes..).

- Heat proof... (Gradacionet e nxehtësisë...)

- We will list the flavors before we serve them (Kur i servirim, i radhisim me shije në pjatancë).

- We can get out 2 liters of concentrated juice (...mund të nxjerrim 2 litra lëng të koncentruar).

- Boil spaghetti as usually. Instead of cheese we put on chopped heavy putargë. (...ziejmë si zakonisht spagetat. Në vend të djathit hedhim putargë të grirë në rende).

- fill in cannelloni ... .( ...mbushim kanelonit...).

- Cooking Raviola ... will take long time (Gatimi i ravioleve... do shumë kohë).

- Boil Lasagne with salt water (Llazanjet i ziejmë me ujë e me kripë).

- The beshamel sauces need to be good clotted (...të jetë mpiksur mirë salca beshamel).

- Parmandie Omelet (Omëletë parmandie).

- $\quad$ Eggs filled shemej (Vezë të mbushura shemej).

- Vellute dressing (Salcë vellute).

- $\quad$ Ravigot dressing (Salcë ravigot).

- Remullade dressing (Salcë remullade).

- Smetana Russian dressing (Salcë ruse me smetanë).

- Mornej dressing ( Salcë mornej).

- $\quad$ Pikadili dressing (Salcë pikadili).

- $\quad$ Fruits should be used of first quality (Frutat që do të përdoren duhet të jenë të kualitetit të parë).

- These sauces serves butinga, Charlotte, croceta (Këto salca shërbejnë për butinga, sharlotë, kroketa)

- $\quad$ Added vanilla syrup, puree, lemon juice, kirsku and mix well (Shtohet në shurup vanilje, pureja, lëngu i limonit, kirsku dhe përzihen mirë).

- It would be better for them to be conservate in terms of home (Do ishte më mirë që ato të konservoheshin në kushtet e shtëpisë).

- The best is to fight fruits in metal container stainless steel or enamelled vessel ( $E$ mira është të zihen frutat në enë metalike prej çeliku të paoksidueshëm ose në enë të emaluara).

- $\quad$ Apple dressing Prevede (Prevede mollësh).

- Fruit Jam (Xhem frutash).

- Zhelèja with agar-agar is better than the gelatin (Zhelèja me agar-agar është më e mirë sesa me xhelatinë).

- Ekler pasta processing presents different variations (Përpunimi i pastave ekler paraqet variacione të ndryshme).

- $\quad$ Tart and tartaletat (Tartat dhe tartaletat).

- Savaren, brushè (Savaren, brushè).

- $\quad$ Fruit Rag (Zhele frutash).

- Milfej (Milfëj).

- $\quad$ Shu filled with praline cream (Shu i mbushur me krem pralinë). 
- Kandigjibek (Kandigjibek).

- Kullure with oranges (Kullure me portokalle).

- Charlotta apple (Sharlot molle).

- $\quad$ Apple souffle (Sufle me mollë).

- $\quad$ Different Tortalete (Tortaletë të ndryshme).

- Carina Oranges (Portokalle të carinës).

- Almina, Carmen, Muritanie Pears (Dardha almina, karmen, muritanie).

- $\quad$ Santigji Cream (Krem santigji)

\section{Sports terminology}

For sports terminology we have selected "Panorama" newspaper ,different days and sports television shows. Some examples of terms that belong to this area are:

- Pirlo refuses Milan (Pirlo refuzon Milanin).

- $\quad$ Renovate with Juventus (Rinovoj me Juventusin).

- I I have been contacted, but I have a contract (Më kanë kontaktuar, por kam kontratë...).

- $\quad$ The Reds look more advantageous ( Të kuqtë duken më të avantazhuar).

- To intensify talks with the player (...të intensifikojnë bisedimet me lojtarin).

- $\quad$ For his transfer to Partizan (Për tranferimin e tij tek Partizani....).

- Remains to be seen how many will continue this resistance (..mbetet për t'u parë sa do të vazhdojë kjo rezistencë....).

- Will be at evacuees contingent (... do të jetë në kontigjentin e të larguarve).

- $\quad$ There are Tirana two objectives for winter merkaton (.. janë dy objektivat e Tiranës për merkaton e dimrit).

- Lika confirmed that there have been contacts (Lika konfirmoi se ka patur kontakte).

- Magani projects removals and avoids interference (Magani projekton largime dhe eviton ndërhyrje).

- The process will be open and transparent ( procesi do të jetë i hapur dhe transparent).

- Muçollari was not in optimal condition (..Muçollari nuk ishte në kondicion optimal).

- To be more complete in the second half (...të jemi më të kompletuar në pjesën e dytë).

- I expect the preparatory destination phase (Po presin destinacionin e fazës pregatitore...).

- Have made immediate entry of leaders in merkato (...kanë bërë imediate futjen e drejtuesve në merkato).

- $\quad$ France is qualified in every competition (Franca kualifikohet në çdo kompeticion).

- $\quad$ All have boycotted training (të gjithë e kanë bojkotuar stërvitjen).

- We had placed an unspecified premium (... kishin vendosur një premio të papërcaktuar..).

- Will probably start on January 6 (..do të startojnë me datë 6 janar).

- Treatatives to bring quality players (.. tratativat për të afruar lojtarë kualitativë).

- With a predominance of the losses columns (... me një dominancë nga kolonat e humbjeve).

- The teams are composed of amateur players (...skuadrat kanë në përbërje lojtarë amatorë). 
- To activate the formation firstly to Dinamo (duke e aktivizuar në formacionin e parë të Dinamos).

- There was not much time available to consolidate the team (“... nuk pati shumë kohë në dispozicion për të kolauduar skuadrën..).

- $\quad$ Negotiate with the Celsi, but I want to stay (Negocioj me Çelësin, por dua të qëndroj).

- Two strongest offensive forces of the championship (..dy forcat ofensive më të fortat e kampionatit....)

- $\quad$ Recovered after knee fissure (...i rikuperuar pas çarjes në gju0

- $\quad$ To support team without reservation (...e mbështesim skuadrën pa rezerva).

- $\quad$ Given the performance of kosovar talent (duke u nisur nga performanca e talentit kosovar).

Information -Technology terminology

Foreign Words in the field of information technology terminology have been selected from two textbooks, from secondary education, namely "Informatica 8" and "Informatic" the authors Lediana Bardhi and Anduela Lile. Since the number of foreign words for each sentence is the minimum 2, there are select to distinguish, since it would have to underline about the whole sentence. The words in bold are unchangeable in many different languages as well as in Albania language too.

- Boot-In Instructions have a limited memory chip ROM, so generally are written in assembler.

- Data are stored on the hard- drive in the computer

- It includes a Desktop background-in a screen background in a screen saver .

- $\quad$ Click Personalize.

- Start Menu operates as a management center .

- It is valid to the Start menu as well as for the Taskbar.

- This procedure does not remove the program from the All Programs list and don't uninstalls the program.

- Thumbtack serves to place a document in the Start menu

- $\quad$ name "Picture Tools" appears at the beginning of ribonit after we entered and selected a painting

- $\quad$ Click the Office button and insert the option Save as

- When inserting an image into a workbook in Excel, formatting tab of the image displayed a ribbon

- $\quad$ Click the button Cut to Clipboard group.

- Word removes the selected text and places it in the clipboard

- Choose Page Layout tab .

- $\quad$ Space "default" appears fields "Space Before" and "Space After" in Paragraph group

- Smart Art Graphics - different diagram

- In Ribon adding two temporary tan-of Desing and Layout, under the label Table Tools

- You can delete using the Backspace or Delete

- To delete columns click Delete Sheet Columns

- Commands Cut, Copy and Paste are executed in the same way as in Word

- The Insert tab, Charts group select the type of schedule that suits your purpose,

- Navigate between the pages by clicking the buttons Next Page and Previous Page

- In the menu Customize Quick Access Toolbar "select the option" Show Below the Ribbon 
- $\quad$ Click the tab Layout Rows and Columns group, and select Insert Right

- Save in box displayed folder in the My Documents

- Commands in groups Alignment, Number and Style are gray, so inactivated

- in Desing tab, Data group, click Switch Row Column

- the display panel double click Blank Document

- images Clip Art in Word

- You can change its style by commands Bold and Italic

- Select Word Art clicking once

- In the Format tab, Text group, click Edit Text

- You can add a total row in table contact, which provides access to some functions, such as: Avarage, Count, Sum, etc.

- in the first group Desing tab, Properties, in the table name field, enter the name of your table

- PowerPoint is part of the Office, a package of products that combines different types of software

- to open Power Point-in click the Start button and the folder in Microsoft Office find and click the program Microsoft Office Power Point 2007

- $\quad$ Click Power Point Presentation to maintain pptx presentation format," default "program Power Point", "page work called slide

- Office button opens the menu that contains commands related to the presentation as a whole, as New, Open, Save, Print, etc.

- $\quad$ Click the Delete button in the group Slide tab Home

- The group Blackground, Desing tab, click Blackground Styles

- $\quad$ All of the above formatting achieved through dialog "Bullets and Numbering

- Click Costumize Bulleted tab, open the Symbol dialog,

- Other objects that you can insert the areas of operation include tables, graphs, diagrams Smart Art, Clipart and video

- $\quad$ Each of these items varies depending selection in the options menu Aling Slide and Aling Selected Objects

- Many SmartArt diagrams you come prepared with special effects animation

- opens the Custom Animation task bar. Notice the buttons are not enabled. Select the text. Add Effect button activated

- Handouts, this option prints some slide on a page.

\section{Bibliography}

[1] Gazeta, "Panorama sport", 26 dhjetor 2013, Tiranë

[2] Gazeta, "Panorama", 25 dhjetor 2013, Tiranë

[3] Kodi penal - I përditësuar me praktikë gjyqësore, Tiranë 200

[4] Kodi civil, Tiranë 2010, Kodi i procedurës administrative, Tiranë 2009

[5] Kodi i procedurës civile, Tiranë 2007

[6] Kodi i procedurës penale, Tiranë 2012 
[7] Kodi i familjes dhe legjislacioni për birësimet, Tiranë 2007

[8] Giovanni Belluscio, Shezai Rrokaj, Fjalor me terma të gjuhësisë, Tiranë 2011.

[9] Lediana Bardhi, Anduela Lile, Informatika 8, Tiranë 2012

[10] Lediana Bardhi, Anduela Lile, Informatika 9 , Tiranë 2012

[11] Vangjel Kullaj, Miço Garuli, Arti i të gatuarit, Tiranë 1998

[12] Kosta Koçi, Arti i pastiçerisë, Tiranë 2005 